\title{
Theoretical perspectives on innovation for waste valorisation in the bioeconomy
}

\section{Bugge, Markus M. ; Bolwig, Simon; Hansen, Teis; Tanner, Anne Nygaard}

Published in:

From Waste to Value: Valorisation Pathways for Organic Waste Streams in Circular Bioeconomies

Publication date:

2019

Document Version

Publisher's PDF, also known as Version of record

Link back to DTU Orbit

Citation (APA):

Bugge, M. M., Bolwig, S., Hansen, T., \& Tanner, A. N. (2019). Theoretical perspectives on innovation for waste valorisation in the bioeconomy. In From Waste to Value: Valorisation Pathways for Organic Waste Streams in Circular Bioeconomies Taylor \& Francis. https://www.taylorfrancis.com/books/e/9780429460289

\section{General rights}

Copyright and moral rights for the publications made accessible in the public portal are retained by the authors and/or other copyright owners and it is a condition of accessing publications that users recognise and abide by the legal requirements associated with these rights.

- Users may download and print one copy of any publication from the public portal for the purpose of private study or research.

- You may not further distribute the material or use it for any profit-making activity or commercial gain

- You may freely distribute the URL identifying the publication in the public portal 


\title{
3 Theoretical perspectives on innovation for waste valorisation in the bioeconomy
}

\author{
Markus M. Bugge, Simon Bolwig, Teis Hansen \\ and Anne Nygaard Tanner
}

\subsection{Introduction}

This book is anchored in a systemic and evolutionary understanding of how society evolves through technological development and innovation that are socially embedded and conditioned by actors, networks and institutions. This chapter outlines the conceptual framework for the empirical case studies in the book, which will present the innovative dynamics of turning waste into value in breweries, forestry-based industry, meat production, dairy production and urban waste management. The chapter starts by introducing the notion of the circular bioeconomy and interpreting it as an ongoing and broader transition in society. Here we account for the generic and pervasive nature of the bioeconomy as well as the benefits and overall objectives associated with the current transition towards a more circular economy. Following this introduction, waste is presented as a potentially valuable resource within the bioeconomy.

We define the term waste as "unwanted or unusable material, substances, or by-products" that are "eliminated or discarded as no longer useful or required after the completion of a process" (Oxford Dictionaries, 2018). In economic terms, waste is "unwanted material left over from a production process, or output which has no marketable value" (Business Dictionary, 2018), implying that the nature of the market (including firms, value chains, infrastructures, consumers, etc.) and not just a material's physical properties determine whether a material is considered waste. Therefore, the elimination of waste in the ideal circular bioeconomy involves changes in both the properties of materials and markets. A distinction can also be made between residues (with no use or market value) and side-streams or by-products (with a value). It follows that waste valorisation means adding value to residues, sidestreams and by-products through changes in markets and/or in the physical properties of these substances, involving both technological and institutional innovation. Finally, valorisation pathways are the trajectories through which such values are created and distributed by and among actors from the private sector, policy, research, civil society and households. At a large spatial and temporal scale, such valorisation pathways may constitute so-called transition pathways, defined as: 
patterns of changes in socio-technical systems unfolding over time that lead to new ways of achieving specific societal functions. Transitions pathways involve varying degrees of reconfiguration across technologies, supporting infrastructures, business models and production systems, as well as the preferences and behaviour of consumers.

(Turnheim et al., 2015)

In this chapter, we initially describe the concept of a circular bioeconomy (section 3.2), before focusing on the role of waste in the bioeconomy (section 3.3). Here, we introduce key concepts such as the waste pyramid and the cascading use principle. In section 3.4 we focus on barriers to waste valorisation and specify lock-in mechanisms that may hinder the transition towards a circular bioeconomy. Conversely, section 3.5 describes drivers for innovation in waste valorisation. Here, we introduce three generations of innovation policies, which reflect different perspectives on the nature and dynamics of innovation: science-driven innovation, systems of innovation and sociotechnical transitions. These perspectives on innovation are then applied to the waste pyramid in order to distinguish between improving an existing system and replacing it with another system higher in the pyramid. In section 3.6 we discuss the roles of policy and governance in order to understand how to avoid or overcome the barriers and challenges associated with the shift towards the bioeconomy. Finally, section 3.7 summarises the chapter.

\subsection{The circular bioeconomy}

Parallel to the emergence of information technologies in the 1970s and 1980s and their subsequent application into the information society, the development of biotechnologies over the last few decades has been an important driver in the transformation of the economy and society towards the bioeconomy. This trend is influenced by, and indeed an important part of, the growing societal emphasis on sustainable development. The emergence and development of the bioeconomy create a potential for a return to (more) circular modes of production and consumption. This implies taking an intersectoral perspective on different industrial activities, where the rest materials from one industry process are utilised as an input in another. The notion of industrial symbiosis encompasses such cross-industry integration, and is based on the co-location and coordination of different industrial activities, which facilitates the exploitation of side-streams and residues.

The bioeconomy is a very broad concept, which encompasses multiple actors and resources and spans several sectors from health and the chemical industry to agriculture, fishery and aquaculture, dairy, slaughterhouses, breweries, forestry and energy. This breadth reflects the generic nature of the notion of the bioeconomy, and some of its potential transformational power. The transition to the bioeconomy is often argued to play a key role in targeting grand challenges such as climate change, food security and renewable 
energies. The bioeconomy might signal a shift (or return) to a circular economy and a society that replaces fossil fuels with renewable energy sources. Yet the broad coverage of the term also means that there are diverging perspectives on the bioeconomy. While some argue that we need to use more pesticides and precision fertilisation in agriculture, others prescribe socalled "no till" and biodiversity to avoid diseases and soil degradation. Rather than a lack of knowledge of how to run the bioeconomy, there is a large variety of contrasting recipes for how to arrive at more circular and sustainable modes of production and consumption. As a consequence, one challenge is to also make sense of these different views and perspectives. In Chapter 2, we outlined three visions of the bioeconomy, which represent one way to handle this breadth in perspectives (Bugge, Hansen \& Klitkou, 2016).

\subsection{The roles of waste in the bioeconomy}

A major strategy in the transition towards the bioeconomy is an improved exploitation of organic residues - previously referred to as waste - and sidestreams from industrial production and household consumption. This implies creating a circular economy in which the outputs from one value chain are used as inputs in another. Hence, what has been formerly regarded as waste in one sector is now turned into a resource for another sector, representing a smarter and more sustainable way of organising and exploiting limited energy and resources.

Figure 3.1 below presents the waste pyramid, which hierarchically ranks different waste treatment options according to their level of sustainability; waste disposal and energy recovery are the least favoured options, while recycling, reuse and prevention are the more favoured and sustainable options. The latter preferred types are usually more resource- and energy-efficient, although there can be trade-offs between resource and energy savings, and they often, though not always, involve lower greenhouse gas emissions. It is, however, important to carefully assess the multiple life cycle impacts for specific options rather than assuming higher or lower general sustainability based on the pyramid's categories (see Chapter 14). Moreover, a specific option may encompass several categories, for example the treatment of waste in a biogas plant involves both recovery (of energy) and recycling (use of the digestate as fertiliser).

The waste pyramid illustrates how side-streams and residues may be processed and utilised in different ways (European Commission, 2008). Historically, waste disposal in landfills has gradually been replaced by innovative and potentially more sustainable forms of waste management, focusing first on energy recovery, and then on recycling, reuse, minimisation and, ultimately, waste prevention. In this book, we conceptualise each of these forms of management as integrated socio-technical systems of production and consumption consisting of key elements, i.e. actors, capabilities, networks, institutions and infrastructures. The composition and characteristics of these elements condition the system's innovative abilities. 


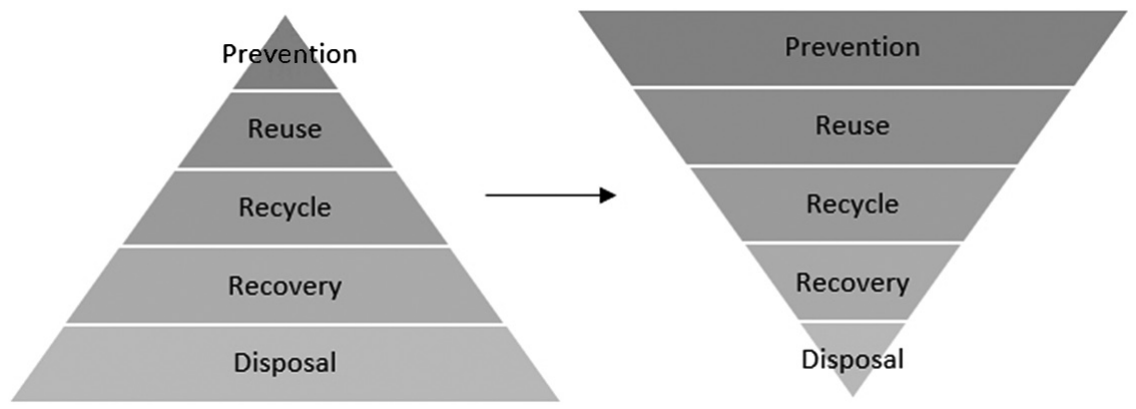

Figure 3.1 The waste pyramid. Innovation in waste systems implies turning the pyramid on its head so that less or no waste is disposed of (hence it is no longer waste), illustrated by a smaller area in the right-hand pyramid, and more waste (or resources) is prevented or reused, illustrated by a larger area in the right-hand pyramid.

In regard to the point made earlier that the bioeconomy consists of diverging perspectives, it is here interesting to note that waste plays various roles and is assigned different values at each level of the waste pyramid depending on the industry and country in focus.

The different socio-technical waste systems represented in the pyramid can co-exist in a given country or region; below we outline each system in turn. In a landfill system, waste has no value but is rather a cost in terms of transport and storage. In a recovery system, waste is an energy resource that can be exploited through incineration, e.g. in district heating or combined heat and power plants. In a recycling system, waste is a potential input to the production of various products such as biofertiliser, animal fodder, nutrition products or recycled materials such as paper, plastics, glass, metals and textiles. In systems of reuse and prevention, waste is avoided altogether, and the food or other biomass retains much of its initial value. One example is a restaurant owned by the student association at the campus of the University of Oslo serving cheap gourmet food which is close to its expiration date (see Chapter 13).

In a circular bioeconomy, the waste pyramid is further substantiated by a cascading use principle. Cascading use has been defined as "the efficient utilisation of resources by using residues and recycled materials for material use to extend total biomass availability within a given system" (European Commission, 2016). In general, cascading utilisation refers to a principle of multiple uses of biomass resources by using residues, recycling resources or recovering resources after consumption. Focus can either be on extending the timespan during which resources stay in the system (cascading-in-time) or on maximising the added value of resources (cascading-in-value) (Olsson et al., 2016). Cascading-in-time (Figure 3.2a) builds on the idea "that resources should be re-used sequentially in the order of the specific resource quality of each stage" (ibid., p. 7). Wood is often used as an example to illustrate the cascading-intime principle (European Commission, 2016; Vis, Reumerman \& Gärtner, 


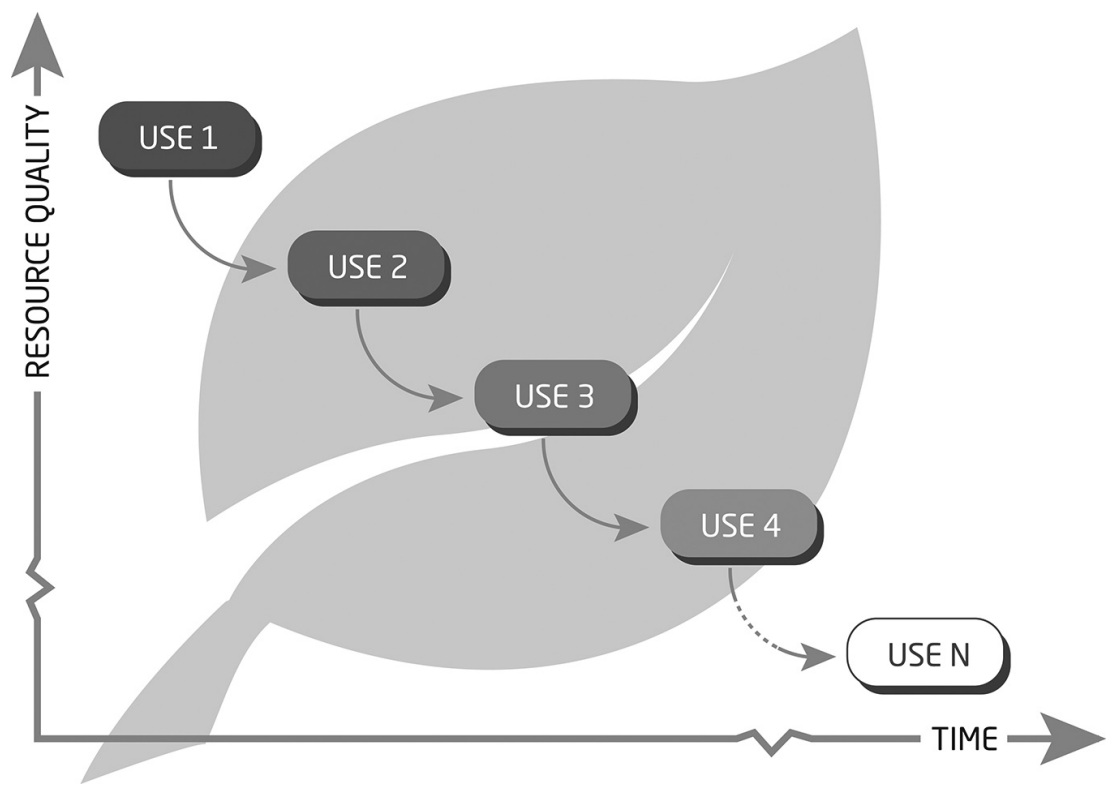

(a)

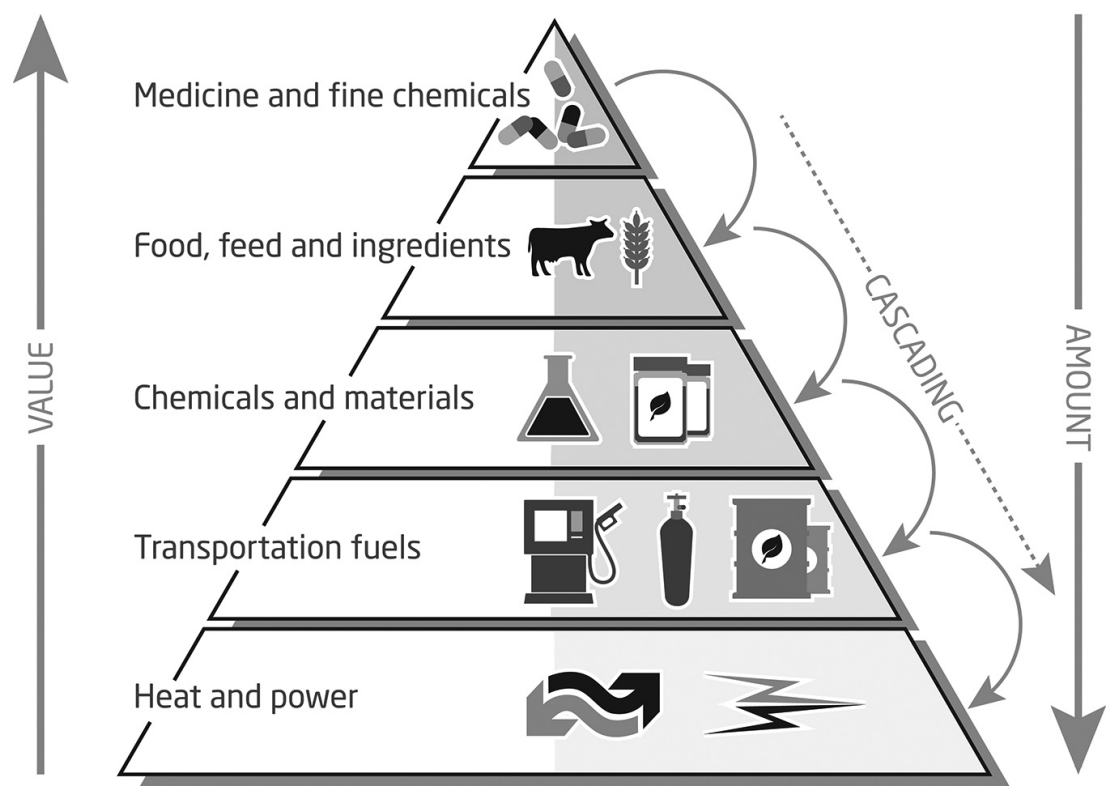

(b)

Figure 3.2 (a) (top): The cascade-in-time chain (adapted from Sirkin \& Houten, 1994); (b) (bottom): The cascade-in-value concept (adapted from Olsson et al., 2016). 
2014), where freshly harvested wood should first be used to veneer wood products, then particle-based products, then fibre-based products, then, finally, biofuels or incineration for heat or power. The cascading-in-value principle (Figure 3.2b) refers to the co-production of several different bioproducts simultaneously, as is characteristic for bio-refineries. Hence, wood can also be used in this principle as cascade fractionation of valuable wood composites in a biorefinery. See Chapter 4 for more details. There can be conflicts between the two forms of cascading. For example, wood that has been reused multiple times is not suitable for biorefining processes, which normally rely on whole, fresh logs to produce various chemicals.

An example of a cascading-in-value use of biomass resources is the efforts made by the meat processing and rendering industry to add more value to animal by-products. During the last decade, incumbent meat processors and rendering companies have established new divisions or subsidiaries dedicated to preventing or utilising side-streams from slaughterhouses, and in so doing have increased the value of their meat processing by selling new products to new markets. At the slaughterhouses, efforts have been focused on reducing the volume of side-streams by utilising a higher proportion of the animal, for example by the export of pig ears, snouts, hooves or gallstones to Asian markets. Other companies have focused on developing new products, such as functional ingredients for the food industry, pet food, animal feed for mink production or, finally, biodiesel. All these initiatives aim to increase the overall value of meat processing and reduce the amount of animal byproducts to be used in the lower part of the waste pyramid. See Chapter 7 for more details on this case.

\subsection{Path dependence and barriers to waste valorisation}

\subsubsection{Path dependence}

Path dependence is the tendency of institutions or technologies to become committed to develop in certain ways because of their structural properties or their beliefs and values (Greener, 2017). Path dependence is important for understanding changes in waste systems as it suggests the existence of mechanisms that (under certain conditions) can cause some technologies, behaviours or policies to persist or dominate even if "superior" alternatives exist. While such lock-in mechanisms cause considerable inertia in waste systems, a change in path-dependent systems is still possible through feedback mechanisms, as highlighted in, for example, studies of strategic niche management (Kemp, Schot \& Hoogma, 1998).

Moving from established value chains in specific industries and sectors to new ones that are cross-sectoral and interwoven through the waste streams involved may require fundamental changes. These changes may take the form of new technologies, altered production modes, infrastructures, logistics and new consumer practices and habits. It can be challenging to change a system 
that has existed for a long period of time, as routinised practices tend to become institutionalised both socially and materially over time. Indeed, for innovation collaborations, there is little empirical evidence that the bioeconomy entails intensified cross-industry collaboration (Bauer, Hansen \& Hellsmark, 2018). This form of path dependence and lock-in (see below) within given socio-technical systems may well prevent or slow down innovation and change (David, 1985; Martin \& Sunley, 2006). The policies and institutions that have emerged to serve and support practices of a given production regime also hold implications for innovation, as existing institutions often reflect the interests and perspectives of the actors that make up these systems. Consequently, changing established practices and waste systems may be challenging due to the existing incentive structures and institutional set-up.

Contributions within evolutionary economic geography have supplemented such a systemic view on path dependence with a historical and evolutionary approach to studying patterns of regional path dependence. The argument here is that the portfolios and competencies of existing industrial actors will often condition the future paths and scenarios for a given sector or region (Boschma, 2015; Boschma \& Frenken, 2006, 2011a, 2011b). To summarise, path dependence may be caused by several factors, both tangible and intangible. In this regard, investments in heavy physical infrastructures and material equipment may be a barrier to change. Repeated social practice and habits may likewise cause segmented cultures and values, which may also serve to prevent or slow down change and innovation. In practice, different combinations of tangible and intangible factors are likely to restrict or limit change and innovation.

In addition to possessing different roles and being subject to valorisation relative to various waste systems, the practices within a given system might constitute barriers towards moving upwards in the waste pyramid. For example, improving and optimising a recycling system might become dependent on generating waste as an input to this system, which would therefore create no incentives for aiming at a waste prevention system. In this sense the established actors, practices, institutions and infrastructures of existing waste valorisation systems might be barriers to a more sustainable system change.

\subsubsection{Lock-in mechanisms}

Klitkou, Bolwig, Hansen and Wessberg (2015) have developed an analytical framework for systematically studying the role of lock-in mechanisms in transition processes. They understand lock-in mechanisms as "mechanisms, which reinforce a certain pathway of economic, technological, industrial and institutional development and can lead to path dependence" (ibid., p. 23). Klitkou et al. (2015) observed that there could be interactions between lockin mechanisms, such as between learning effects, network externalities and technological interrelatedness, which are reinforcing each other, while other 
interactions could have weakening effects. These mechanisms also have different functions in the different stages of path development. Only in the last stages will the process get locked in and become path-dependent (Sydow, Schreyögg \& Koch, 2009). Moreover, non-predictability and coexistence of several outcomes normally characterise the start of the process, while inflexibility and inefficiency are typical for the later stages. Table 3.1 summarises the mechanisms discussed by Klitkou et al. (2015), including key literary sources.

The influences of learning effects, and economies of scale and scope, are evident in the forestry industry. Pulp and paper firms continue to prioritise incremental improvements relating to existing processes and products, which

Table 3.1 Lock-in mechanisms potentially affecting waste valorisation

\begin{tabular}{|c|c|c|}
\hline Lock-in mechanism & Description & Key sources \\
\hline Learning effects & $\begin{array}{l}\text { Specialisation leads to increasing returns from } \\
\text { learning in relation to existing products and } \\
\text { production processes. }\end{array}$ & $\begin{array}{l}\text { Arthur (1990); } \\
\text { Cimoli (1994) }\end{array}$ \\
\hline $\begin{array}{l}\text { Economies of } \\
\text { scale }\end{array}$ & $\begin{array}{l}\text { Earlier investment in production equipment } \\
\text { leads to increasing returns from additional } \\
\text { built-up and further investments in this } \\
\text { production system. }\end{array}$ & $\begin{array}{l}\text { Hughes (1983, } \\
\text { 1987) }\end{array}$ \\
\hline $\begin{array}{l}\text { Economies of } \\
\text { scope }\end{array}$ & $\begin{array}{l}\text { Existing product specialisations may guide } \\
\text { diversification into new product groups due } \\
\text { to potential cost efficiencies. }\end{array}$ & $\begin{array}{l}\text { Panzar and Willig } \\
\text { (1981) }\end{array}$ \\
\hline $\begin{array}{l}\text { Technological } \\
\text { interrelatedness }\end{array}$ & $\begin{array}{l}\text { Existing technologies lead to favourable } \\
\text { conditions for development of technologies } \\
\text { with complementarities. }\end{array}$ & $\begin{array}{l}\text { Van den Bergh and } \\
\text { Oosterhuis (2008); } \\
\text { Boschma and } \\
\text { Frenken (2011b) }\end{array}$ \\
\hline $\begin{array}{l}\text { Network } \\
\text { externalities }\end{array}$ & $\begin{array}{l}\text { Uptake of existing technologies leads to de } \\
\text { facto standard setting due to institutionalised } \\
\text { use patterns. }\end{array}$ & $\begin{array}{l}\text { Katz and Shapiro } \\
(1986) ; \text { David } \\
(1985)\end{array}$ \\
\hline $\begin{array}{l}\text { Informational } \\
\text { increasing returns }\end{array}$ & $\begin{array}{l}\text { Uptake of existing technologies leads to } \\
\text { increasing knowledge and attention about } \\
\text { them, further stimulating their diffusion. }\end{array}$ & $\begin{array}{l}\text { Van den Bergh and } \\
\text { Oosterhuis (2008) }\end{array}$ \\
\hline Collective action & $\begin{array}{l}\text { Uptake of existing technologies leads to } \\
\text { development of societal norms, customs and } \\
\text { formal regulations, which further stimulates } \\
\text { their diffusion. }\end{array}$ & Foxon (2002) \\
\hline $\begin{array}{l}\text { Institutional } \\
\text { learning effects }\end{array}$ & $\begin{array}{l}\text { Existing formal institutions limit the } \\
\text { possibilities for establishing new policies, } \\
\text { which are not aligned with them. }\end{array}$ & Foxon (2002) \\
\hline $\begin{array}{l}\text { Differentiation of } \\
\text { power and } \\
\text { institutions }\end{array}$ & $\begin{array}{l}\text { Incumbent organisations may exercise power } \\
\text { to prevent institutional change to their } \\
\text { disadvantage; change of institutions is } \\
\text { hampered by institutional complementarities. }\end{array}$ & $\begin{array}{l}\text { Foxon }(2002) ; \\
\text { Ostrom, Schroeder } \\
\text { and Wynne (1993) }\end{array}$ \\
\hline
\end{tabular}


have long been their central profit-generating activities. The firms' core competencies closely relate to these activities, making it hard to change technologies (Laestadius, 2000). Moreover, the capital intensity of the industry implies that firms have made large investments in existing equipment. Consequently, few commercial-scale investments target the conversion of side-streams into new high-value products, which require obtaining knowledge about new markets and techniques. Furthermore, adding new technologies to an existing production system in a mill is highly complicated due to the economic importance of avoiding pauses in the production process (Bauer, Coenen, Hansen, McCormick \& Palgan, 2017; Hansen \& Coenen, 2017). However, in some cases bottlenecks in the production process may be overcome by extracting components (e.g. lignin). Subsequently, these substances may form the basis of new product lines. This underlines the importance of considering economies of scope in moving up the waste pyramid (Gregg et al., 2017). For lignin, this allows moving into a variety of new products from binders to fuels and speciality chemicals, rather than simply recovering the energy for use in the production process. See Chapter 4 for more details on this case.

In urban waste systems, path dependence is created by large investments in technological and physical infrastructure. In the municipality of Oslo, investments in an optical sorting plant and a biogas plant constitute an advanced system for managing organic household waste. Organic waste is sorted by the households in plastic bags with different colours, collected at the kerbside and sorted optically at the sorting plant. The waste is then treated mechanically and chemically and used for producing biofertiliser and biogas. The biofertiliser is sold to regional farms and the biogas is used for public bus transport. It exemplifies a circular system for waste recycling. Yet it is also a system that depends on constant flows of organic waste (Uyarra \& Gee, 2013), and which may create disincentives for reducing or preventing waste generation in the first place (Bulkeley \& Gregson, 2009; Mourad, 2016). Therefore, investments in one system of waste treatment create path dependence where economies of scale (e.g. investments in infrastructure) and scope (e.g. optical sorting of multiple waste fractions) are mechanisms that prevent leaps up the waste pyramid. See Chapter 5 for more details on this case.

The dairy sector provides a third example of how lock-in mechanisms can influence and reinforce innovation and value chain development in the bioeconomy. The Danish dairy cooperative Arla Foods is one of the largest dairy companies in the world. Because of a series of mergers and acquisitions, as well as specialisation in whey, over the past few decades, Arla Foods benefits from economies of scale, economies of scope and learning effects. The subsidiary Arla Foods Ingredients was created to find solutions to whey processing and utilisation at a time when new regulations restricted the disposal of whey as waste. This move not only created a long-term learning effect through a niche specialisation in whey handling and processing, but also expanded the product range of the company. Today, Arla supplies proteinbased food ingredients within six product categories: paediatric nutrition, 
sports nutrition, medical nutrition, health foods, bakery and dairy. Through investments in state-of-the-art production equipment as well as in research and development in the context of globalisation, Arla has achieved significant market power, further increasing its ability to exploit the advantages of economies of scope and scale. See Chapter 9 for more details on this case.

\subsection{Drivers of innovation in waste valorisation}

To better understand the drivers and challenges associated with enabling a shift towards a circular bioeconomy, we here discuss the literature on innovation and innovation policies. Schot and Steinmueller (2018) distinguish between three generations of innovation policies in terms of different perspectives on what constitutes the main drivers of innovation and with respective implications for innovation policies. In the 1960s, innovation was primarily seen to emerge from research and scientific discovery. This view of innovation was very much oriented around technological development and scientific discovery and a belief in the commercialisation of new technologies and scientific breakthroughs. However, from the 1990s this view was supplemented by a more pronounced systemic understanding of how innovation occurs through impulses from user needs in the market and through the interplay and collaboration between various types of actors (Edquist, 1997; Lundvall, 1992).

Such a systemic understanding of innovation also implies supplementing the supply-oriented focus on the role of science with demand as also determining and conditioning innovation. The scholarly tradition on systems of innovation has shown how innovation should not be understood as isolated phenomena, but rather as being the output from collaboration and interactive learning across diverse types of actors that possess various and complementary capabilities. Moreover, it has illustrated how the spatial embeddedness and context for the industry actors, such as networks, institutions, infrastructures and policy frameworks, may also strongly affect innovation performance in firms, sectors and regions. This has been elaborated in the economic geography literature on path development, which specifies how regional characteristics condition future development opportunities, outlines the various stages in path development processes and considers the role of agency (Martin, 2010; Simmie, 2012). Each sector within the bioeconomy has traditionally consisted of established value chains and industrial processes where different inputs and resources - labour, investments, biological resources, technologies, infrastructures, policies and management - determine how value is created in the respective sectors. These value chains can thus be viewed as conditioned by their surrounding systems of innovation.

From the 2000s, the systemic understanding of innovation was complemented by research on socio-technical transitions, which has served to reconsider and broaden conventional innovation theories and policies by focusing on how entire systems may need to change more fundamentally. Particularly 
important for this focus on transformative change has been the multi-level perspective, which sees systemic transitions as co-evolutionary processes that unfold through an interplay between three interrelated analytical levels; regimes, niches and landscapes (Geels, 2002, 2004, 2005; Geels \& Schot, 2007; Schot \& Geels, 2008). A regime refers to an existing dominant system of production and consumption, niches are the locus for disruptive innovation and landscapes are understood as contextual factors conditioning regimes and niches. This tradition represents an important discontinuity in the main object of study from "innovations" to "transitions in socio-technical systems". Whereas the systems of innovation tradition were primarily driven by a technological and economic logic, the turn to socio-technical transitions has introduced a stronger sense of society beyond the economy and technological development.

Our discussion of these three perspectives reveals that opinions differ regarding what actors are important for driving innovation forward (Schot \& Steinmueller, 2018). In a traditional understanding of innovation processes, the focus is on universities and research institutes as well as private firms, which are seen as central to making scientific discoveries and their commercialisation through the introduction of technical innovations in the market.

In the context of the waste pyramid, this implies a focus on improving technologies in the lower part of the pyramid, i.e. developing new and improved recovery and recycling processes. Examples are technologies that improve the efficiency in the recovery process, leading to a higher production of electricity and heat, or developments in recycling technologies that improve the quality of the sorting or reduce the need for other inputs such as electricity and labour.

The innovation system perspective broadens out the types of actors seen as important in innovation processes. Firms, universities and other knowledge institutions are still considered to play a key role, but inputs from users and customers are also seen to provide important inputs. Furthermore, public sector actors are attributed a central position, not least as the systemic emphasis underlines the importance of intermediaries (Kivimaa, Boon, Hyysalo \& Klerk, 2018). The latter are organisations with a focus on connecting and brokering between other actors in the system, e.g. technology transfer offices and cluster and network organisations. Many intermediaries are public or quasi-public bodies, but are increasingly also established by private interest organisations or as independent private enterprises.

The systems perspective on innovation in waste prevention and handling also implies a focus on technological innovations in the bottom part of the pyramid. Yet, unlike the science-driven model of innovation, it will assign a stronger prominence to the interactions between various actors in different parts of the value chain, e.g. between actors in recycling and energy recovery, or between goods producers and recycling firms. Therefore, innovation is not perceived as the result of activities taking place within specific firms and organisations but rather as caused by their collaboration and interactions. 
The transformative change perspective further broadens the actors considered important to innovation - and transition - processes. This includes groups traditionally considered outsiders to innovation processes such as civil society groups and interest organisations (Coenen, Hansen \& Rekers, 2015; Geels \& Raven, 2006). The emphasis on entire socio-technical systems implies that the development and production of technical artefacts are seen as closely connected to their use and associated social practices. Thus, users and consumers are not only regarded as input providers to innovation processes, but as important agents that may preserve or challenge regimes.

In a transformative change perspective on waste, innovation efforts are beneficial when they contribute to transitioning the waste system towards an increasing emphasis on the upper parts of the waste pyramid, i.e. recycling and especially preparing for reuse and prevention. Hence, this perspective gives less attention to incremental improvements of process technologies in the lower parts of the pyramid. Indeed, improvements in energy recovery technologies may be viewed as counterproductive to transformative change since they disincentivise efforts and investments in developing the higher parts of the waste pyramid.

\subsection{Governance for waste valorisation}

Reflecting the three generations of innovation perspectives introduced in the previous section, the role and scope of policy and governance of innovation have steadily developed and expanded over the last 50 years (Schot \& Steinmueller, 2018). This trend represents a move from an initial emphasis on the role of new technologies themselves to the role of a range of other social, geographical, institutional and organisational factors affecting innovation.

An important distinction between the three generations of innovation policy discussed above is that the first two have a generic focus on innovation and growth, whereas the overall objectives and primary goals of the third generation are solutions to specific societal challenges (Schot \& Steinmueller, 2018). In a linear model of innovation (first-generation innovation policy), one would invest in $\mathrm{R} \& \mathrm{D}$ to develop technologies that could help exploit waste in new ways. An innovation systems perspective (second-generation innovation policy) would develop innovative and cost-effective systems of waste collection and treatment across public, private and civic sectors, enabling a cost-effective exploitation of all possible forms of rest-products from consumption. A transitions perspective (third-generation innovation policy) would, however, put the social values of sustainability upfront and let these guide the search for more sustainable consumption in the first place (e.g. eco-designs such as reducing portions or organic packaging). Instead of aiming for optimising and greening existing value chains, a transitions mode would typically question the existence of the value chain altogether. In this sense, a transitions mode of innovation takes a broader perspective on the entire value chain. 
Exemplifying this trend, and showing how diverse actor groups are crucial to innovation, Fagerberg (2017) has examined the main drivers behind Danish wind power, the German Energiewende and Norwegian electromobility. It is concluded that the social drivers have been more important than the technologies themselves, which had often been around for decades. Instead, the forces that seemed the most powerful in determining the pace and scope of these socio-technical transitions were those associated with the practices and interests of (local) user groups.

Thus, although there has been a continuous expansion in terms of the roles of policy and high-level governance in arranging for systemic innovation and system change, this does not eliminate the need for governance at the microlevel. Here, governance can be in the form of developing and renewing the competencies, routines, value chains and business models of individual organisations and within the boundaries of specific sectors. This illustrates how governance of waste may be diverse and manifold, depending on the case and context. In the subsequent chapters, we present case studies on innovation in waste valorisation in various industry sectors such as forestry, aquaculture, breweries, dairies and slaughterhouses. We also present a case study on urban waste systems, which supplements the production focus in the industry cases with a focus on the public sector and the consumer side of waste. So, depending on the case and context in question, various forms and levels of governance for waste valorisation are actualised.

Below we discuss how directionality towards specific societal goals and missions is often a result of multiple initiatives and practices that co-evolve at different levels and across various types of societal sectors and actors.

\subsubsection{Directionality through international regulations}

Amidst the widespread agreement on the need to include diverse types of actors in the governance of innovation, the literature on socio-technical transitions further argues that a strong element of priorities and directionality is required to accomplish certain missions or to arrive at more profound system changes - so-called socio-technical transitions (Mazzucato, 2017; Schot \& Steinmueller, 2018; Shove \& Walker, 2007; Smith \& Raven, 2012; Smith, Stirling \& Berkhout, 2005; Weber \& Rohracher, 2012). Regarding organic waste, the UN sustainable development goals (United Nations, 2015), the Paris Agreement and the EU landfill ban in 2009 are central landscape elements that frame and guide international development in this area (see Chapter 5 on urban waste management and Chapter 13 on multi-level governance of food waste).

\subsubsection{Directionality through national regulations}

Directionality may also be set at national levels. In Norway, the recent Industry agreement on the reduction of food waste (Regjeringen, 2017) represents a 
similar sense of directionality, which is likely to guide innovations and behaviours in the years to come. The agreement aims to reduce food waste by $50 \%$ by 2030 , and illustrates the importance of not underestimating the role of the private and civic sectors in the innovative dynamics towards more sustainable waste systems.

Indicators and performance measurement systems also often operate at national levels. In order to facilitate transition, Huguenin and Jeannerat (2017) suggest replacing "innovation" with "valuation" to ensure that the solutions address the most pressing societal questions. They propose to focus on the purpose behind developments in the economy and society, e.g. reducing greenhouse gas emissions, rather than on the factors contributing to these developments, e.g. strengthening $\mathrm{R} \& \mathrm{D}$ budgets or university-industry collaboration. Such an approach, they argue, would give innovative work a clear societal direction and "mission" and thus better facilitate addressing important issues in the first place. Similarly, Papargyropoulou et al. (2014) have applied the waste pyramid to food waste and call for a holistic approach to food waste that takes into account all production and consumption activities in global food value chains, i.e. agriculture, food processing and manufacturing, retail and consumption. Such a broad lens would also favour adding social and cultural aspects to the usual suspects of technology and economy. Preventing food waste could involve changes in technology and infrastructure in harvesting, storage, transport and distribution, and also in consumer-related issues such as the promotion of eco-designs and eco-labels, re-sizing of products and portions, and taxation of non-sustainable packaging (European Commission, 2008). Having food waste prevention as the overall concern represents an important objective and capability. Supporting this broader perspective on organic waste valorisation might be a way to avoid or overcome the risk of causing lock-ins or path dependencies when introducing solutions, practices or systems of production and consumption in the lower parts of the waste pyramid. See Chapter 13 on multi-level governance and food waste.

\subsubsection{Directionality through industrial practices}

Nonetheless, most learning, innovation and development work is anchored and embedded in existing and localised organisations, incentive structures and value chains. When individual organisations apply the transition agenda in their daily operations there may well be unresolved issues in terms of how to interpret a given challenge or task as falling under either "business as usual" or as "here there is reason to rethink the way we do things". We know that the two options imply and involve fundamentally different actors, approaches and resources. Therefore, this points back to the importance of innovation policies and governance in terms of giving direction, articulating demands, mobilising relevant stakeholders and arranging for joint reflexivity and learning (Weber \& Rohracher, 2012). 
The literature on private forms of governance within firms and along value chains offers insights into the dynamics of firms and industries that can augment second- and third-generation perspectives on innovation.

Along value chains, global value chain (GVC) scholars highlight how firms acquire capabilities and access new market segments ("upgrade") through participation in specific value chains, where learning from downstream firms is seen as a central upgrading mechanism (Bolwig, Ponte, du Toit, Riisgaard \& Halberg, 2010; Gereffi \& Lee, 2016). Value chain governance is the process by which so-called "lead firms" organise activities with the purpose of achieving a certain functional division of labour within a chain. It involves setting the terms of chain membership, such as prices or the compliance with technical, environmental and legal standards. It also includes the way in which such market requirements are implemented along the chain, and how they affect chain participation for firms, the re-allocation of value-adding activities and the distribution of costs and benefits (Gibbon, Bair \& Ponte, 2008). In the context of waste valorisation, the GVC perspective and the governance mechanisms just mentioned suggest that the capabilities and incentives of innovation are strongly influenced by the nature of the inter-firm linkages and power relationships in specific markets. Yet, similarly to the trend within innovation studies, recent GVC literature highlights that a broader range of actors, such as governments, standard-setters and NGOs, can yield significant influence on value chain governance, especially in emerging industries such as renewable energy (Nygaard \& Bolwig, 2018; Ponte \& Sturgeon, 2013).

At the firm level, scholars have long studied the links between private sustainability measures or corporate social responsibility (CSR) on the one hand and the competitive advantage to companies on the other. See Chapter 6 on brewing. In the brewing industry, CSR efforts include the sustainable use of organic residues, reduced water consumption, waste water management, more efficient energy use and diminished $\mathrm{CO}_{2}$ emissions, sustainable packaging and responsible drinking. To pursue a competitive advantage, companies must choose between product differentiation and low costs in terms of cost leadership (Porter, 1985). CSR serves as a means of product differentiation by functioning as a co-specialised asset that makes other assets more valuable (McWilliams \& Siegel, 2011). Most evident here is the effect of CSR on reputation or branding (Roberts \& Dowling, 2002). Branding and reputation are hard-to-get resources that cannot be imitated and thus serve as entry barriers to competitors (Reinhardt, 1998). Hence CSR can serve as a means for obtaining a sustainable competitive advantage (McWilliams \& Siegel, 2011). In this context, a review of 200 studies by Clark et al. (2015) found a positive association between companies' sustainability measures and their economic performance in terms of the cost of capital, operational performance and stock price, although the direction of causality is ambiguous. Despite such benefits, Whelan and Fink (2016) observe that sustainability and broader CSR measures are only rarely placed at the core of a business's strategies. 


\subsection{Summary}

In this chapter we have discussed the notion of the circular bioeconomy, the drivers and barriers for adding value to waste and thereby creating a more sustainable bioeconomy, and the special role of governance including innovation policy in developing the bioeconomy. There are many views on the bioeconomy, which is an emerging area for research, policy and economic activity. Our focus has been on the role of innovation in waste valorisation, not only technological but also social and institutional innovation.

We have discussed the waste pyramid that illustrates the hierarchy of alternative forms of waste management in terms of resource efficiency and sustainability, and the associated notion of cascading use of biological resources. We conceptualised the alternative forms of waste management as integrated sociotechnical systems of production and consumption. This concept provided a gateway into the studies on socio-technical transitions, innovation and governance that we claim are central for analysing the patterns and dynamics of waste valorisation.

The drivers of innovation in waste valorisation were approached through a discussion of three generational perspectives on innovation and innovation policy. Today, many scholars have come to understand innovation in the bioeconomy as transformative change. This perspective focuses on the upper parts of the waste pyramid (recycle, reuse and prevention), emphasises entire sociotechnical systems and not only considers companies, researchers and policy makers as agents, but also intermediary organisations, users and consumers. Hence, analysis of the dynamics of bio-economic value chains should consider not only the firm actors handling the products and technologies, but also the broader institutional, economic and social context of production and trade.

The barriers to innovation in the bioeconomy were discussed through the concepts of path dependence and lock-in mechanisms. Economic, institutional and social mechanisms may cause inertia in waste systems and constrain an upward movement in the waste pyramid, and there are important regional and sectoral dimensions of path dependence arising from the characteristics of specific industries. The Swedish pulp and paper industry is an example thereof. However, under the right conditions, the same mechanisms, e.g. learning effects and economies of scale, may bring waste systems onto a more sustainable path, as illustrated by the case of whey valorisation in Arla Foods.

Governance is essential to understanding and enhancing waste valorisation. The concept not only comprises public policy, but also private governance by firms within value chains, as well as the activities of civil society organisations, industry organisations and consumer groups. Another key insight is that the governance of production, consumption and innovation is not an abstract process but is instead deeply rooted in existing value chains, organisations and localities. Firm efforts to gain sustainable competitive advantage through product differentiation (including CSR) or cost reductions can spur innovations in waste valorisation, while the incentives and capabilities to undertake 
innovation not only originate within the firm but also at the level of the value chain or "value network" comprising various non-commercial actors.

Finally, recent contributions to the transitions literature have emphasised the need for a much stronger "directionality" in the governance of sustainable innovation as well as a focus on social values as the key driver of sustainable development. For example, a holistic approach to food waste should first consider social values related to food production and consumption, including ecology, health and food waste prevention, as well as processes and impacts along entire global value chains. Such a broader perspective on waste systems, we argue, would help overcome transition issues related to path dependence and lock-in, thereby paving the way for the circular bioeconomy.

\section{Acknowledgements}

This work was supported by the Research Council of Norway (grant number 244249). Tobias Pape Thomsen created the artwork.

\section{References}

Bauer, F., Hansen, T. \& Hellsmark, H. (2018). Innovation in the bioeconomy: Dynamics of biorefinery innovation networks. Technology Analysis \& Strategic Management, 30, 935-947. doi:10.1080/09537325.2018.1425386.

Bauer, F., Coenen, L., Hansen, T., McCormick, K. \& Palgan, Y. V. (2017). Technological innovation systems for biorefineries: A review of the literature. Biofuels, Bioproducts and Biorefining, 11(3), 534-548. doi:10.1002/bbb.1767.

Bolwig, S., Ponte, S., du Toit, A., Riisgaard, L. \& Halberg, N. (2010). Integrating poverty and environmental concerns into value chain analysis: A conceptual framework. Development Policy Review, 28(28), 173-194.

Boschma, R. A. (2015). Towards an evolutionary perspective on regional resilience. Regional Studies, 49(5), 733-751. doi:10.1080/00343404.2014.959481.

Boschma, R. A., \& Frenken, K. (2006). Why is economic geography not an evolutionary science? Towards an evolutionary economic geography. Journal of Economic Geography, 6(3), 273.

Boschma, R. A., \& Frenken, K. (2011a). The emerging empirics of evolutionary economic geography. Journal of Economic Geography, 11(2), 295-307.

Boschma, R. A., \& Frenken, K. (2011b). Technological relatedness and regional branching. In H. Bathelt, M. Feldman \& D. F. Kogler (Eds.), Beyond Territory: Dynamic Geographies of Knowledge Creation, Diffusion, and Innovation (pp. 64-81). London and New York: Routledge.

Bugge, M., Hansen, T. \& Klitkou, A. (2016). What is the bioeconomy? A review of the literature. Sustainability, 8(691), 1-22.

Bulkeley, H., \& Gregson, N. (2009). Crossing the threshold: Municipal waste policy and household waste generation. Environment and Planning A, 41, 929-945.

Business Dictionary. (2018). Waste. www.businessdictionary.com.

Clark, G. L., Feiner, A. \& Viehs, M. (2015). From the Stockholder to the Stakeholder: How Sustainability Can Drive Financial Outperformance. Retrieved from https:// arabesque.com/research/From_the_stockholder_to_the_stakeholder_web.pdf. 
Coenen, L., Hansen, T. \& Rekers, J. V. (2015). Innovation policy for grand challenges: An economic geography perspective. Geography Compass, 9(9), 483-496. doi:10.1111/gec3.12231.

David, P. A. (1985). Clio and the economics of QWERTY. American Economic Review, 75(2), 332-337.

Edquist, C. (1997). Systems of Innovation: Technologies, Institutions and Organizations. London: Pinter.

European Commission. (2008). Directive 2008/98/EC of the European Parliament and of the Council of 19 November 2008 on Waste and Repealing Certain Directives. Official Journal of the European Union.

European Commission. (2016). Study on the Optimised Cascading Use of Wood. Brussels: European Commission.

Fagerberg, J. (2017). Mission (Im)possible? The Role of Innovation (and Innovation Policy) in Supporting Structural Change and Sustainability Transitions. TIK Working Papers on Innovation Studies. TIK Centre, University of Oslo. Retrieved from http://ideas. repec.org/s/tik/inowpp.html.

Geels, F. W. (2002). Technological transitions as evolutionary reconfiguration processes: A multi-level perspective and a case-study. Research Policy, 31(8-9), 1257-1274. doi:10.1016/S0048-7333(02)00062-8.

Geels, F. W. (2004). From sectoral systems of innovation to socio-technical systems: Insights about dynamics and change from sociology and institutional theory. Research Policy, 33(6-7), 897-920.

Geels, F. W. (2005). Processes and patterns in transitions and system innovations: Refining the co-evolutionary multi-level perspective. Technological Forecasting $\mathcal{E}$ Social Change, 72(6), 681-696.

Geels, F. W., \& Raven, R. (2006). Non-linearity and expectations in nichedevelopment trajectories: Ups and downs in Dutch biogas development (1973-2003). Technology Analysis \& Strategic Management, 18(3-4), 375-392. doi:10. 1080/09537320600777143.

Geels, F. W., \& Schot, J. (2007). Typology of sociotechnical transition pathways. Research Policy, 36(3), 399-417.

Gereffi, G., \& Lee, J. (2016). Economic and social upgrading in global value chains and industrial clusters: Why governance matters. Journal of Business Ethics, 133, 25-38.

Gibbon, P., Bair, J. \& Ponte, S. (2008). Governing global value chains: An introduction. Economy and Society, 37(3), 315-338.

Greener, I. (2017). Path dependence. In Encyclopedia Britannica. Retrieved from: www.britannica.com/topic/path-dependence.

Gregg, J., Bolwig, S., Hansen, T., Solér, O., Ben Amer-Allam, S., Pladevall Viladecans, J., ... Fevolden, A. (2017). Value chain structures that define European cellulosic ethanol production. Sustainability, 9(1), 118.

Hansen, T., \& Coenen, L. (2017). Unpacking resource mobilisation by incumbents for biorefineries: The role of micro-level factors for technological innovation system weaknesses. Technology Analysis \& Strategic Management, 29(5), 500-513. doi: 10.1080/09537325.2016.1249838.

Huguenin, A., \& Jeannerat, H. (2017). Creating change through pilot and demonstration projects: Towards a valuation policy approach. Research Policy, 46(3), 624-635.

Kivimaa, P., Boon, W., Hyysalo, S. \& Klerk, L. (2018). Towards a typology of intermediaries in sustainability transitions: A systematic review and a research agenda. Research Policy, In Press. doi:doi.org/10.1016/j.respol.2018.10.006. 
Klitkou, A., Bolwig, S., Hansen, T. \& Wessberg, N. (2015). The role of lock-in mechanisms in transition processes: The case of energy for road transport. Environmental Innovation and Societal Transitions, 16(September), 22-37.

Laestadius, S. (2000). Biotechnology and the potential for a radical shift of technology in forest industry. Technology Analysis \& Strategic Management, 12(2), 193-212.

Lundvall, B. A. (1992). National Systems of Innovation: Towards a Theory of Innovation and Interactive Learning (B.-Å. Lundvall Ed.). London: Pinter.

Martin, R. (2010). Roepke Lecture in economic geography: Rethinking regional path dependence: Beyond lock-in to evolution. Economic Geography, 86(1), 1-27. doi:10.1111/j.1944-8287.2009.01056.x.

Martin, R., \& Sunley, P. (2006). Path dependence and regional economic evolution. Journal of Economic Geography, 6(4), 395-437.

Mazzucato, M. (2017). Mission-Oriented Innovation Policy: Challenges and Opportunities (RSA Action and Research Centre Ed.). London, UK: UCL Institute for Innovation and Public Purpose.

McWilliams, A., \& Siegel, D. (2011). Creating and capturing value: Strategic corporate social responsibility, resource-based theory, and sustainable competitive advantage. Journal of Management, 37(5), 1480-1495.

Mourad, M. (2016). Recycling, recovering and preventing "food waste": Competing solutions for food systems sustainability in the United States and France. Journal of Cleaner Production, 126 (10 July), 461-477.

Nygaard, I., \& Bolwig, S. (2018). The rise and fall of foreign private investment in the jatropha biofuel value chain in Ghana. Environmental Science \& Policy, 84(June), 224-234. doi:10.1016/j.envsci.2017.08.007.

Olsson, O., Bruce, L., Hektor, B., Roos, A., Guisson, R., Lamers, P. \& Thrän, D. (2016). Cascading of Woody Biomass: Definitions, Policies and Effects on International Trade. Retrieved from www.ieabioenergy.com/publications/cascading-of-woodybiomass-definitions-policies-and-effects-on-international-trade.

Oxford Dictionaries. (2018). Waste. www.oxforddictionaries.com.

Papargyropoulou, E., Lozano, R., Steinberger, J. K., Wright, N. \& Ujang, Z. b. (2014). The food waste hierarchy as a framework for the management of food surplus and food waste. Journal of Cleaner Production, 76(August), 106-115.

Ponte, S., \& Sturgeon, T. (2013). Explaining governance in global value chains: A modular theory-building effort. Review of International Political Economy, 21(1), 1-29. doi:10.1080/09692290.2013.809596.

Porter, M. E. (1985). The Competitive Advantage: Creating and Sustaining Superior Performance. New York: Free Press.

Regjeringen. (2017). Industry agreement on reduction of food waste. Retrieved from www.regjeringen.no/contentassets/1c911e254aa0470692bc311789a8f1cd/industryagreement-on-reduction-of-food-waste_norway.pdf.

Reinhardt, F. L. (1998). Environmental product differentiation: Implication for corporate strategy. California Management Review, 40(4), 43-73.

Roberts, P. W., \& Dowling, G. R. (2002). Corporate reputation and sustained superior financial performance. Strategic Management Journal, 23(12), 1077-1093.

Schot, J., \& Geels, F. W. (2008). Strategic niche management and sustainable innovation journeys: Theory, findings, research agenda, and policy. Technology Analysis \& Strategic Management, 20(5), 537-554.

Schot, J., \& Steinmueller, W. E. (2018). Three frames for innovation policy: R\&D, systems of innovation and transformative change. Research Policy, 47(9), 1554-1567. 
Shove, E., \& Walker, G. (2007). CAUTION! Transitions ahead: Politics, practice, and sustainable transition management. Environment and Planning A, 39(4), 763-770.

Simmie, J. (2012). Path dependence and new technological path creation in the Danish wind power industry. European Planning Studies, 20(5), 753-772. doi:10.108 0/09654313.2012.667924.

Smith, A., \& Raven, R. (2012). What is protective space? Reconsidering niches in transitions to sustainability. Research Policy, 41(6), 1025-1036.

Smith, A., Stirling, A. \& Berkhout, F. (2005). The governance of sustainable sociotechnical transitions. Research Policy, 34(10), 1491-1510.

Sydow, J., Schreyögg, G. \& Koch, J. (2009). Organizational path dependence: Opening the black box. Academy of Management Review, 34(4), 689-709.

Turnheim, B., Berkhout, F., Geels, F. W., Hof, A., McMeekin, A., Nykvist, B. \& van Vuuren, D. (2015). Evaluating sustainability transitions pathways: Bridging analytical approaches to address governance challenges. Global Environmental Change, 35(November), 239-253. doi:10.1016/j.gloenvcha.2015.08.010.

United Nations. (2015). Resolution adopted by the General Assembly on 25 September 2015: Transforming our world: The 2030 Agenda for Sustainable Development Retrieved from: www.un.org/ga/search/view_doc.asp?symbol=A/RES/70/1\&Lang=E (accessed 23. $01.2018)$.

Uyarra, E., \& Gee, S. (2013). Transforming urban waste into sustainable material and energy usage: The case of Greater Manchester (UK). Journal of Cleaner Production, 50(1), 101-110. doi:10.1016/j.jclepro.2012.11.046.

Vis, M. V., Reumerman, P. \& Gärtner, S. (2014). Cascading in the Wood Sector: Final Report. Retrieved from Enchede, The Netherlands.

Weber, K. M., \& Rohracher, H. (2012). Legitimizing research, technology and innovation policies for transformative change: Combining insights from innovation systems and multi-level perspective in a comprehensive "failures" framework. Research Policy, 41(6), 1037-1047.

Whelan, T., \& Fink, C. (2016). Sustainability: The comprehensive business case for sustainability. Harvard Business Review, 21(October). 